\title{
Parental Leave in the Czech Republic and Slovakia - WHERE IS It MORE FAVOURABLe TO BECOME A FATHER?
}

\author{
Denisa Nevická $^{1}$, Juraj Hamul’ák $^{2}$, Mikuláš Krippel ${ }^{3}$
}

\begin{abstract}
The article deals with the position of the child's father in labour relations. The comparative analysis of legislation in the Czech Republic and Slovakia is based not only on labour law, but also on social security law and anti-discrimination law. The authors aim to point out the difference in treatment and answer the fundamental research question - In which country is it easier for a man to reconcile work and family responsibilities?
\end{abstract}

\section{Keywords}

Father, Social Security, Employer, Employee, Parental Leave, Discrimination

\section{Introduction}

The position of the child's father in labour relations and the social security system is a topic which is not frequently examined by the public or in professional practice. Historically, labour law regulations in the Czech Republic and Slovakia have focused primarily on the protection of the mother in labour relations. Similarly, the mother historically benefited from all the benefits of the social security system in childcare (Hanáková, Havelková, Oates-Indruchová, 2015). However, society is evolving and labour relations and social security systems should evolve at the same pace. The authors decided to follow up on their previous article The Comparative Analysis of Women's Status in Labour Relations in Modern Slovakia and the Czech Republic to build on the issue of women's protection by a comprehensive analysis and comparison of the position of children's fathers in labour relations and social security system in the Czech Republic and Slovakia. At the same time, the authors also analyse the newly adopted directive No. 2019/1158 of the European Parliament and the EU Council on the work-life balance of parents and care givers (referred to as the "work life balance directive").

\footnotetext{
${ }^{1}$ The Comenius University in Bratislava, Šafárikovo nám. 6, 81000 Bratislava, Slovakia. E-mail: denisa.nevicka@flaw.uniba.sk.

2 The Comenius University in Bratislava, Šafárikovo nám. 6, 81000 Bratislava, Slovakia. E-mail: juraj.hamulak@flaw.uniba.sk.

3 The Comenius University in Bratislava, Šafárikovo nám. 6, 81000 Bratislava, Slovakia. E-mail: mikulas.krippel@flaw.uniba.sk.
} 


\section{The Status of Men in Labour Relations in the Czech Republic and Slovakia}

When analysing the status of male worker - father in labour relations in the Slovak Republic, it is necessary to proceed primarily in accordance with the Act No. 311/2001 Coll. - the Labour Code (hereinafter referred to as the "Slovak Labour Code") and the Act No. 365/2004 Coll. - Act on Equal Treatment in Certain Areas and Protection against Discrimination (hereinafter the "Slovak Anti-Discrimination Act"). According to above mentioned regulations, the child's father is either the biological father of the child or the father to whom the child has been placed into custody based on a court decision. The introductory articles of the Slovak Labour Code, as well as provisions of the Slovak Anti-Discrimination Act, clearly ban discrimination on grounds of sex. Discrimination on grounds of sex shall also include discrimination on grounds of pregnancy and maternity, as well as discrimination on grounds of gender or gender identification. Women and men are provided with working conditions that enable them to perform a social function in the upbringing and care of children (Barancová, 2003). Thus, already in the introductory provisions, a problem may be encountered. The pregnant woman and the mother of the child are protected explicitly in the sense of labour law and anti-discrimination law on the grounds of sex, but neither of the acts provides a male worker - a father with paternity protection (Freel, 2018). In the Czech Republic, the position of the father in labour relations is regulated by the Act No. 262/2006 Coll. - the Labour Code (hereinafter referred to as "The Czech Labour Code") and Act No. 198/2009 Coll. on equal treatment and legal remedies for protection against discrimination (hereinafter referred to as The Czech Anti-Discrimination Act) (Bobek, Boučková, Kuhn, 2007). According to the Czech Anti-Discrimination Act, discrimination on grounds of sex also includes discrimination on grounds of pregnancy, maternity, paternity, or sexual identification (Halířová, 2014). In the Czech Republic, the father of the child is clearly protected from discrimination in the exercise of his parental rights, while in the Slovak Republic, for the same protection, the legislation would have to be extended or a case law issued by the Supreme Court of the Slovak Republic.

The issue of pre-contractual relations in labour law is closely related to parenthood. The Slovak Labour Code explicitly stipulates the employer's prohibition to ask future employees questions related to their marital status and at the same time exhaustively defines other areas that the employer may not ask about. Pursuant to article 41, the employer may require only such information as is related to the work to be performed (Freel, 2018). Pursuant to the Labour Code of the Czech Republic, namely article 316, the employer may only require information that is related to the performance of work. Future employer shall not require information about future employee's family relationships and other areas of demonstration demarcation. The difference between the Czech and Slovak legislation is therefore an exhaustive definition of the areas that the employer must not ask the future employee about before the employment relationship in the Slovak legal order and the demonstrative calculation of this area in the Czech law. The Czech legislation provides more extensive protection for future employees. Under the conditions of the Slovak republic, employees would have to refer to the provisions of Slovak Anti- 
Discrimination Act and wait for a lengthy trial. It is precisely the issue of pre-contractual relations that most affects the parents of children. Research confirms (Bygren, Erlandsson, Gähler, 2017) that employers prefer childless men when choosing their future employees. There is no need for discussion about the fact that women are discriminated against many times when accessing employment because of pregnancy and maternity. However, the professional public overlooks the fact that even men who perform parental responsibilities may be discriminated against in accessing the profession compared to those who do not have children. This is mainly related to the gradual introduction of measures that enable fathers to participate more equally in the upbringing of children. These rights are not yet at the level of the mother's rights in the upbringing of the child in the field of labour relations. Although the employer does not have the right to ask the prospective employee about marital status or to obtain this information through a third party, in accordance with both legislation under review, he or she can access it on social networks or by asking cunning questions, e.g. questions about the use of kindergarten in the workplace. Studies show that up to $90 \%$ of discrimination in pre-contractual relationships occurs during the first selection phase of an employee (Attström, 2007). Gender discrimination, parenthood and ethnicity are the most common forms of discrimination that occur in pre-contractual relationships (Åslund, Nordström, 2012).

With the care of the child, the father-employee has the right to parental leave in accordance with both examined legislation. The child's father is entitled to parental leave from the date of birth until the child's three years of age (if the child is in good health), depending on the extent to which the employer applies for. Both regulations give the employee time off with wage compensation at the birth of the child, but only necessary time to transport the mother and the child to and from the medical facility. In addition, the Czech legislation provides the employee with time off without paying wages to participate in childbirth. Unlike Slovak legislation, under the Czech legislation, a child's father is entitled to a paternity leave of 1 week that cannot be divided or interrupted and must be exhausted within 6 weeks of the child's birth, otherwise it will forfeit. Similar legislation is also envisaged in the directive on work-life balance, which provides for paternity leave of 10 working days after the birth of a child. In so doing, the directive leaves it to the national legislation whether paternity leave is to be taken in part before or after the birth of the child and whether it can be taken in flexible forms. In contrast to the current Czech legislation, the right to paternity leave should not be linked to the period of service, the duration of the employment relationship and the marital or family status of the child's father. In this respect, it should be noted that the work life balance directive is to be transposed by 02nd of August 2022 and will bring a significant change and a step towards equality in the legal conditions of the Slovak Republic for the fathers of children (Hamulák, Nevická, 2018). In the Czech Republic, changes to align with the work life balance directive can also be envisaged, but at least to some extent paternity leave is already granted to fathers in the Czech Republic.

Other rights of the child's father include the possibility of applying for an adjustment of working time as long as he permanently cares for a child under 15 years of age. Both Czech and Slovak employers must comply, provided they are not prevented by serious operational reasons (Haliŕová, 2014). Pursuant to the judgment of the Czech Supreme 
Court no. 612/2006, serious operational reasons are assessed on a case-by-case basis, according to the employer's operating conditions and those of the applicant employee. The flexibility of working time arrangements as well as the flexibility of the place of work is also envisaged in the work life balance directive. Flexible forms of work organization should be possible for both parents of a child up to 8 years of age, not only with regard to working time but also place of work. Czech legislation prohibits employers from ordering overtime work for men caring for a child under one year of age. Employees taking care of a child under 8 years of age can be sent on a business trip only with their consent. The Slovak legislation allows overtime work for an employee who permanently cares for a child up to 3 years of age, but it cannot be ordered, the overtime work can be only performed based on mutual consent. Posting for a business trip is subject to a general consent, no further consent is required from a staff member caring for a child under the Slovak Labour Code. The provisions about annual leave are also closely linked to the organization of working time (Poruban, 2019). While in the Czech Republic the annual leave is provided to employees without distinction in the duration of at least 4 weeks, in the Slovak Republic there has been a significant amendment since 2020. Employees under the age of 33 who are permanently caring for a child are entitled to at least 5 weeks of annual leave and employees over 33 are automatically entitled to at least 5 weeks of leave. Due to the very brief wording of the Slovak Labour Code, all parents who are permanently caring for a child are entitled to 5 weeks of leave, regardless of their gender, child's age, or even alternating care. However, there was a recent development in this area and employees must inform their employer that they are permanently taking care of a child in writing.

As we have already mentioned, there are differences in the possibility of overtime working hours. While in the Czech Republic overtime for fathers caring for a child under 1 year of age is prohibited, in the Slovak Republic it is possible by agreement. We consider the possibility of an agreement more favourable to the employee, as overtime work is also associated with the wage advantage that many employees rely on. The need for additional consent when posting on business trips for employees - fathers caring for a child under 8 years of age is considered positively from the authors' point of view and allows the reconciliation of parental responsibilities not only to mothers but also to fathers of young children. In the opinion of the authors, a 5-week annual leave arrangement for parents who are constantly caring for a child is a good intention, reflecting also the amount of school holidays that children have within a year, but it is not sufficiently regulated by law in Slovakia. The article 103 of Slovak Labour Code stipulates: "Leave of an employee who is at least 33 years old by the end of the relevant calendar year and an employee who is permanently caring for a child is at least five weeks" is insufficient. Application practice is confronted with the problems of entitlement to leave during of the birth of the child, the age of the child, the absence of a common household or the custody or adoption of the child. We are of the opinion that the current diction requires the most extensive interpretation possible, giving 5 weeks' entitlement to both the father and the mother of the child, if they are constantly looking after the child. The issue is currently being assessed by the Supreme Court of the Slovak republic. 


\section{The Status of Men in Social Security System in the Czech Republic and Slovakia}

The Slovak legal order provides men with considerable opportunities in childcare, unlike the legal systems of countries such as Great Britain and Ireland (Hamulák, Nevická, 2018). Pursuant to Art. 166 para. 1 of the Slovak Labour Code father of the child is entitled to parental leave from the child's birth in the same extent as the mother. In practice, this means 28 weeks, or approximately 7 months. While a woman in the Slovak Republic has to take maternity leave immediately after giving birth, otherwise she loses her entitlement, the child's father can take parental leave according to Art. 166 par. 1 at any time up to 3 years of child's age. During this period, the father receives maternity benefit. The law allows parents to take turns, but the child's father must take the child into his care by written agreement with the mother, otherwise the maternity benefit will not be paid. The amount of the benefit in question is based on the insured's assessment base and the father must have been insured for at least 270 days during two years before claiming the maternity benefit. The maternity benefit is provided at $75 \%$ of the daily gross wage assessment base, which is close to the employee's net wage. In spite of the fact that fathers in the Slovak Republic have the opportunity to claim maternity benefit during parental leave, the number of fathers - employees who use this option still does not reach even half of the number of entitled persons. In 2018, only about 12836 fathers drew on maternity leave (Krippel, 2019). Working during parental leave and maternity leave is not prohibited by law, but a person who is on parental leave must provide full day care for the child. Directly The Act No. 461/2003 Coll. on social insurance in Art. 140 stipulates that if the child's father works while receiving maternity benefit, he is excluded from paying social security contributions, but this income must not come from the employment from which the child's father is on parental leave. Thus, the child's father could lawfully perform work for an employer other than the one from whom he is released for parental responsibilities. Notwithstanding this provision, in practice there are a number of problems in granting maternity benefits, in particular to fathers.

Following the first part of parental leave in duration of 28 weeks, the father of the child can take parental leave up to 3 years or up to 5 years of age of the child depending on the health condition of the child according to Art. 166 par. 2 of the Slovak Labour Code. This kind of parental leave is designed to deepen childcare and the child's father receives a state social benefit - parental allowance. The amount of the parental allowance depends on whether the father of the child would be entitled to receive the maternity benefit, regardless of whether he actually received it. If he would not have been entitled to maternity benefit, he will receive $€ 270$ / month / child, if he would have been entitled to maternity benefit, he will receive $€ 370$ / month / child (Freel, 2018). Parental leave may be taken simultaneously by the mother and the father in accordance with the legislation of the Slovak Republic, but only one of the parents will be entitled to the parental allowance. The father of the child is not entitled to any other special paternity leave under the legal order of the Slovak Republic, nor is he entitled to a special social security benefit if he wishes to take care of the child immediately after birth (Freel, Kováčiková, 2013). 
In addition to parental leave, the Czech Republic also offers fathers the possibility to take paternity leave and receive paternity benefit. The paternity benefit is a sickness insurance benefit belonging to the child's father in connection with the care of the newborn child for 7 days. It is a social insurance benefit and during this time the father - employee has a justified obstacle to work but does not receive any wage compensation from the employer. The father of the child can determine the period between the birth of the child up to 6 weeks of age the child to take this 7-day paternity leave. The condition for the payment of a paternity benefit is participation in sickness insurance in an employment relationship or through self-employment. While taking paternity leave, the child's father will receive a paternity benefit of $70 \%$ of the reduced daily gross wage assessment base. At a gross income of $€ 1470$, the child's father receives approximately $€ 226$ for 7 days of paternity leave. An important condition is that the child's father must be registered in the child's birth certificate to qualify for the paternity benefit, but the child's parents do not have to be married.

In the Czech Republic, the possibility of father - employee to take parental leave was established in 1990. Since 2001, the possibility for fathers to take parental leave is similar to that in the Slovak Republic, meaning two parts of parental leave - parental leave after the birth of the child and parental leave to take care of the child up to the age of three. Unlike the Slovak legislation in the Czech Republic, a man's entitlement to parental leave does not, by definition, refer to a woman's maternity leave. In the Czech Republic, this leave is called exclusively parental leave. In accordance with the Czech Labour Code, the child's father may take parental leave from the child's birth to the extent he applies for, but no longer than three years of child's age. As in the Slovak Republic, the first part of parental leave is considered to be 28 weeks after birth and the second part of parental leave is the period from 28 weeks after birth till 3 years of child's age (Halîrová, 2014). During parental leave, the child's father may receive two types of social benefit. The first is called maternity benefit. The child's father may receive the maternity benefit from the 7 th week after childbirth, provided that the child's mother does not receive this benefit. The child's father can receive the maternity benefit for a maximum of 22 weeks, but this period also includes the time when the child's mother received the maternity benefit. Unlike fathers in the Slovak Republic, whose entitlement to receiving the maternity benefit for 28 weeks is not dependent on the mother's drawing of the benefit, in the Czech Republic the father can only receive as much maternity benefit as the child's mother does not use (Halîrová, Melotíková, 2018). The father can stay at home with child, while the mother is receiving the maternity benefit, but he will be without any entitlement to state social benefit. A similar condition for the payment of social benefit as in the Slovak Republic is the obligation of the mother of the child to agree in writing, that the father will take care of the child. This must be either the father of the child mentioned in the birth certificate or the husband of the mother. The amount of maternity benefit is similar to that of the paternity benefit, $70 \%$ of the reduced daily assessment base, provided that father's sickness insurance is still in place and he was insured at least for 270 days during the last two years. The amount of the maternity benefit is therefore significantly lower compared to the Slovak Republic, although it is dependent on income and the legal order determines similar conditions for 
entitlement. As well as Slovak legislation, Czech legislation does not preclude a father from doing dependent work while receiving a maternity benefit, if it is a different type of work for current employer or work for an employer other than the one releasing him on parental leave.

After the first phase of childcare during which can the father receive maternity benefit, he can move on to the second phase, which serves to deepen the care of the child up to 3 years of child's age. The health of a child is not taken into consideration, unlike in the Slovak Republic. During this period, the child's father may receive parental allowance. Entitlement to parental allowance does not affect whether the child's father is working or not, but he must ensure day care of the child; it does not have to be personal. If the child's father was insured in sickness before entitlement to the parental allowance, he can determine the amount of the parental allowance on his own (Halirrová, Melotíková, 2018). The maximum drawdown period is 4 years, with the state providing a maximum of $€ 11018$ per child for the entire drawdown period. The maximum monthly allowance is $€ 1522$. The amount of the allowance depends on the parent's income and on the parent's daily assessment base, as in the case of maternity benefit. This flexibility allows both the father and the mother of the child to determine the length of the contribution period as well as its amount according to the current family needs. The choice of the drawing amount can be changed every 3 months and, as in the Slovak Republic also in the Czech Republic, it is not possible for the parents to receive a parental allowance for the same child at the same time. For parents who opt for a parental allowance for a maximum period of 4 years, the average parental allowance paid is $€ 256$ per month.

In the area of social security law, the issue of providing maternity benefit to working fathers in the Slovak Republic also appears to be a problematic area based on the authors' analysis. Although the concept of care is not legally defined, the Social Insurance Agency has adopted all-day personal care as a rule of interpretation in providing maternity benefit to fathers and does not grant maternity benefit to those fathers who perform dependent work in addition to caring for the child. To date, 66 actions have been filed against the Social Insurance Agency by fathers who have not received maternity benefits. The decisions of lower courts are not uniformed, and they do not contribute to legal certainty of working fathers. As we have mentioned, the problematic area is performing work in addition to parental leave while receiving maternity benefit. The Social Insurance Agency asks the fathers to adjust the working conditions so that they can take care of the child in accordance with the legal regulations during the active part of the day and on a daily basis. In previous decisions, the courts of the Slovak Republic decided 14 times in favour of the Social Insurance Agency and 4 times in favour of the children's fathers (Krippel, 2019). We believe that the conditions for granting the benefit should be clearly set out in such a way that there are no differences between the father and the mother of the child and that the fathers also have clear rules on the extent to which they can work to be granted the benefit in question. The legislator should clearly specify in the Social Insurance Act what is considered to be care of a child when receiving a maternity benefit and what conditions the parent of a child must fulfill in order to receive the benefit in question. As a good example serves the scheme of parental allowance in both countries, where it is 
clearly established to what extent a third party can take care of the child to ensure that the conditions of care are met and thus the parental benefit is granted. In the Czech Republic, we have not experienced a similar problem to such a significant extent at present as in Slovakia.

\section{Analysis of the Results and Reflections de lege ferenda}

In labour relations in both countries, we find many similar institutes, such as the possibility to ask for adjustment of working time, prohibition to ask questions during a job interview on marital status, or the father's right to drive a mother to a maternity hospital. However, the position of men - fathers in labour relations in the Slovak Republic is weaker than men - fathers in the Czech Republic based on our analysis of legal regulations. The most dominant differences from the labour law point of view are the introduction of 5 weeks of leave for employees under the age of 33 and constantly caring for children in the Slovak legislation and the existence of a discriminatory reason - paternity in the Czech legislation. Already in the introductory provisions of both anti-discrimination laws it is possible to see a significant difference and problem for the Slovak Republic (Freel, Kováčiková, 2013). A woman is considered discriminated on grounds of sex due to pregnancy and maternity, while paternity is not mentioned in the Slovak Anti-Discrimination Act. On the other hand, Czech legislation clearly considers discrimination caused by paternity to be discrimination on grounds of sex. The authors believe that the Slovak legislation needs an urgent amendment. Given the gradual mandatory changes, such as the planned paternity leave 10 days after the birth of the child or 5 weeks of leave for persons under 33 years of age caring for child, it is essential that men are also protected by labour law and anti-discrimination law due to parenthood - paternity. This is apparent from the work life balance directive as well as many of the European Union's strategies, which have the common goal of increasing father's-employee's involvement in childcare by taking parental leave and flexible forms of work organization. When we grant more rights to child-raising fathers, it is necessary to provide them with sufficient legal protection to exercise those rights.

As a model example for the implementation of the work life balance directive, but also the formation of rules for a more balanced representation of both parents in the position of employees in childcare is the so-called Swedish model, or the legislation of the Kingdom of Sweden. Sweden was the first country in the European Union to introduce paid parental leave for fathers in 1974 (Chronholm, 2007). Sweden has become a model for new legislation on parental leave for libertarian and progressive access to childcare. Parental leave in Sweden gives parents a total of 480 days of parental leave, of which at least 90 days belong to the mother and 90 days to the father (Ekberg, Eriksson, Friebel, 2013). During the first 390 days, the child's parents are entitled to almost $80 \%$ of their average daily wage, but a maximum of $€ 92$ per day, which is approximately $€ 2576$ per month. The remaining 90 days are paid flat rate. To be eligible for paid parental leave, the duration of the employment relationship and the payment of contributions to social security system must be at least 240 days prior to the birth of the child are required (Hamulák, Nevická, 2018). Those who do not fulfill this condition are entitled to a social benefit. Parents have 
the right to take leave of up to 8 years of age and at the same time they have the right to ask the employer to reduce their working time by up to $25 \%$, which they are obliged to comply with. Another advantage that the Swedish system provides to parents is the 10-day paid leave of the father after the birth of the child. The equal distribution of parental leave was also reflected in the real drawdown of parents. An analysis by the Swedish National Social Insurance Agency showed that up to $27 \%$ of the total cost of parental benefits was paid to the father of the child, which is up 6.9\% more than in 2012 (Ekberg, Eriksson, Friebel, 2013). On the basis of the above, it can be concluded that the Swedish model provides greater involvement of the father in childcare and has allowed more women to return to work, thus bringing a greater degree of equality in family care between men and women. In the future, it can therefore be proposed from the labour law point of view that the definition of discrimination on grounds of sex shall be extended to include discrimination reason paternity in the Slovak Republic. At the same time, the authors are of the opinion that the introduction and support of more flexible forms of work like home office or flexibility of the place of work where the work allows it, is another supportive tool in involving the child's father - employee in the care of the child.

Similarly, we have found that in social security law of the two countries under comparison, a large number of legal provisions are less favourable for a father - employee in childcare than for a mother. Both the Slovak Republic and the Czech Republic do not use the unified concept of parental leave such as the Kingdom of Sweden (Hamulák, Nevická, 2018). The legal systems distinguish between the concepts of maternity leave, parental leave, and paternity leave. In introducing the concept of parental leave, the Czech Republic sought a conceptual unification that would not divide employees into care by gender, but subsequently adopted a special social benefit called paternity leave and retained the use of the title maternity benefit even for fathers. Similarly, in Slovakia, the benefit provided to fathers is called maternity benefit. We believe that unifying concepts and eliminating a strict distinction between the rights of fathers and mothers would contribute to parental equality in childcare, while at the same time eliminating the established stigma of employers that only women may potentially care for the child. Although the European Directive on worklife balance uses the term second parent, it is neither used in the legislation of the Slovak Republic nor the Czech Republic. Legislation imposes rights and obligations in relation to childcare and social security entitlements only to the mother and father.

Another problematic area appears to be in the mother's obligation to hand over the child in writing to the father in order for him to receive maternity benefit. This institute is similar in both countries. The authors of the article are of the opinion that this is a discriminatory provision in legal systems that clearly disadvantages a father in the position of an employee in the care of a child compared to the mother of the child. For entitlement to benefit the parenthood must be proven by the father by child's birth certificate in which he is registered as the father of the child or by a court decision awarding the child to his custody. At the same time, for the period when the father receives maternity benefit, the mother must give up these benefits. These instruments should be sufficient for the social insurance institutions to grant the father the right to benefit from the social insurance scheme after the other legal conditions have been met. The necessity of the father of the child to seek 
written consent from the mother to take the child into his custody also appears to be discriminatory, because the mother is not obliged to ask the father for consent to care for the child in order to be granted maternity benefit (Krippel, 2019). We understand that historically, the institute of taking a child into care has been justified with regard, for example, to breastfeeding, but at present, when the labour codes of both countries provide mothers with paid breastfeeding breaks, this argument is not sufficient. The legal entitlement of fathers to parental leave under the legal regulations arises, but whether they will be provided with social security benefit depends on the decision of the mother. The legal provisions in question also appear to be incorrect in the light of the European Union's initiative to equalize childcare for both working parents and to enable the mother of the child to take part in the work process sooner rather than later. The legislation of the Czech Republic is even stricter than in Slovakia, because it allows fathers to draw only the amount of financial assistance in maternity that the mother did not use. Thus, 28 weeks of financial assistance is intended for both parents of the child, and there is no mandatory part that is not transferable from parent to parent. We consider the legislation of the Slovak Republic to be more equal in this area, since both the mother and the father of the child have the same time and the same way of calculating the entitlement to maternity leave, regardless of whether the other parent drew the maternity benefit or not (Krippel, 2019). Furthermore, we must state that we consider the Czech flexible setting to be a very positive and appropriate model for providing parental allowance. Not every employee can afford to stay at home for 3 years for less than $€ 300$ per month, so the flexible setting allows parents to pay intensive care to the child during the first 2 years with a contribution that will not have such a significant negative impact on family finances and consequently allows them to work again. We also evaluate positively the amount of the parental allowance according to the parents' daily assessment base, meaning according to the employee's actual income. The flat-rate increase in parental allowances in the Slovak Republic reflects to a certain extent the income of parents - employees, but it is based more on the solidarity principle and means a high rate of loss for high-income parents. The authors consider the Czech model of providing parental allowance more favourable and supporting the reconciliation of family and work duties.

\section{Conclusion}

The role of the father in labour relations and in the social security law should express the equal role of the father in family and professional duties (Krippel, 2019). We have come to a number of conclusions when examining the issue. Primarily, we have to state that the position of the father in labour relations and in the system of social security law seems to be more progressive in the Czech Republic. Fathers - employees in the Czech Republic have a legal entitlement to paternity leave, flexible drawing of parental benefit and, during the whole period of childcare, they are also protected by the anti-discrimination law in labour relations. On the other hand, in the Slovak Republic, paternity is not explicitly expressed as gender discrimination ground in legislation. In spite of this, fathers in the Slovak Republic are more equally set to take parental leave of 28 weeks and maternity benefit from the social insurance system is not bound to the maternity benefit, unlike in 
the Czech Republic. It can therefore be stated that every legal system has both positive and negative aspects, but the Czech Republic is closer to the model recommended by the European Union reaching the balanced childcare by both parents (Freel, 2018). If the Czech legal system provided for a non-transferable portion of parental leave for each parent and the paternity leave was extended to 10 days, we would consider this model to be satisfactory and favourable to the child's father, in accordance with the adopted directive on work-life balance. However, the authors consider a great problem in both countries to be the bureaucracy involved in claiming benefits during parental leave. The obligation to reach childcare agreement between the mother and the father of the child not only appears to be discriminatory against the father of the child by the state, but at the same time this obligation gives the mother of the child much greater authority in deciding on childcare. If both countries consider it necessary to submit the agreement in question to assess entitlement to a social security benefit, it should be introduced for both parents.

Based on the submitted analysis, we can conclude that the Czech Republic and the Slovak Republic have undergone a significant and progressive change in the issue of childcare from the perspective of a father - employee since the division. While in the communist regime the caretaker role was in practice exclusively for women, and the fathers of children were not largely involved, the current regulation considers the importance of the child's father's position in his or her upbringing. The role of labour law, anti-discrimination law and social security law should be to create optimal conditions for the equal involvement of both parents in childcare while enabling them to reconcile family and working life. We believe that both countries are moving towards a model of equal treatment, but the existing shortcomings that have been highlighted in the comparative analysis need to be removed.

\section{References}

Åslund, O., Nordström Skans, O. (2012). Do anonymous job application procedures level the playing field? Industrial and Labor Relations Review, 65, 82-107.

Attström, K. (2007). Discrimination against Native Swedes of Immigrant Origin in Access to Employment. International Migrations Papers 86E. Geneva: International Labor Office. Barancová, H. (2003). European labor law. Bratislava: Sprint. 186 pp. ISBN 80-8908513-x.

Bobek, M.; Boučková, P.; Kuhn, Z. (2007). Equality and Discrimination. Edit. 1. Prague: C. H. Beck, 471 pp. ISBN 978-80-7179-584-1.

Bygren, M., Erlandsson, A., Gähler, M. (2017). Do employers prefer father? Evidence from Field Experiment Testing the Gender by Parenthood Interaction Effect on Callbacks from Job Applications. European Sociological Review, 33(3), 337-348, ISSN 0266-7215. Ekberg, J., Eriksson, R., Friebel, G. (2013). Parental Leave - A Policy Evaluation of the Swedish "Daddy-Month" Reform. Journal of Public Economics, 97, 131-143.

Freel, L. (2018). Father on Maternity Benefit. Bratislava: CU the Faculty of Law. 1st edit. Pg. 47-52. ISBN 978-80-7160-491-4.

Freel, L.; Kováčiková, J. (2013). Constitutional Definition of Women's Special Working Conditions and Their Position on the Labor Market. Wien: Paul Gerin. ISBN 978-3-20003147-0. 
Halir̃ová, G. (2014). The Reconciliation of Family and Work Roles of Employees taking Care of Children. Leges. 192 pg. ISBN 978-80-8757-692-2.

Halir̂ová, G., Melotíková, P. (2018). The Practical Problems of Social Security Law. Leges. 176 pg. ISBN 978-80-8757-642-7.

Hamulák, J., Nevická, D. (2018). Swedish model of parental leave - the way to equality? In Proceedings of the International Scientific Conference "The Rule of Law - Between Science and Art" as a part of the International Scientific Congress Trnava Law Days, 20th-21st of September 2018. Trnava: Faculty of Law, The University of Trnava, 2018. Bratislava: Wolters Kluwer, 2018.

Hanáková, P., Havelková, H., Oates-Indruchová, L. et al. (2015). Expropriated voice: Changes in gender culture of Czech society 1948-1989. Praha: The Sociological Publishing House.

Chronholm, A. (2007). Father's Experience of Shared Parental Leave in Sweden. Recherches Sociologiques et Anthropologiques, 38(2), 9-25.

Krippel, M. (2019). The Conditions of Father's Entitlement to Maternity Benefit. Bratislava: CU the Faculty of Law. 1st edit. Pg. 323-334. ISBN 978-80-7160-517-1.

Poruban, A. (2019). Parental leave and the actual performance of work creating the right to annual leave. Justičná revue, 3/2019, 315-321. 